\title{
Corporate Governance as Privately-Ordered Public Policy: A Proposal
}

\author{
Lynn Stout ${ }^{*}$ and Sergio Gramitto* ${ }^{* *}$
}

\begin{abstract}
In this Article, we show how our society can use corporate governance shifts to address, if not entirely resolve, a number of currently pressing social and economic problems. These problems include: rising income inequality; demographic disparities in wealth and equity ownership; increasing poverty and income insecurity; a need for greater innovation and investment in solving problems like disease and climate change; the "externalization" of many costs of corporate activity onto third parties such as customers, employees, creditors, and the broader society; the corrosive influence of corporate money in politics; and discontent and loss of trust in the capitalist system among a large and growing segment of the population.

We demonstrate how, to a very significant extent, these problems can be traced to the way shares in business corporations are currently owned, traded, and voted. We also offer a plausible plan for shifting the structure of share ownership, trading, and voting to create a more democratic and sustainable capitalism that allows business corporations to better serve humanity. Our proposal, which envisions developing a new form of institutional shareholder, does not rely either on market forces or government interventions. Rather, it relies on voluntary cooperation and the private ordering of free individuals using modern information

\footnotetext{
* Distinguished Professor of Corporate and Business Law and Director of the Clarke Program on Corporations and Society, Cornell Law School.

** Visiting Assistant Professor of Law and Assistant Director, Clarke Program on Corporations and Society, Cornell Law School... The authors would like to thank Tamara Belinfanti, Frank Partnoy, Saule Omarova, Odette Lienau, Jeff Rachlinski, Jesse Fried, Sidney Tarrow, Aziz Rana, Bradley Wendel, Daniel Greenwood, Jennifer Hill, Andrea Tina, Lynne Taylor, Shelley Griffiths, Struan Scott, Ursula Cheer, and David Ciepley for their comments and suggestions, along with participants at workshops on and presentations of this paper given at Cornell Law School, the Berle Conference held at Georgia State University, the University of Otago in Dunedin, the University of Canterbury in Christchurch, the University of Milan, and Victoria University of Wellington.
} 
technologies. It operates to reduce inequalities not only in wealth and income but also in influence over business corporations.

\section{INTRODUCTION}

Change begins with imagining something better. In this Article, we imagine a future where our society has ameliorated, if not resolved, a number of currently pressing social and economic problems. These problems include: rising socioeconomic inequality; racial and generational disparities in participation in equity markets; increasing poverty and income insecurity; inadequate innovation and investment in solving problems like disease and climate change; the "externalization" of many costs of corporate activity, such as carbon emissions, systemic risk, and the degradation of human health, onto third parties (customers, employees, creditors, the broader society); the corrosive influence of corporate money in politics; and the disengagement and alienation of large and growing segments of the population, leading to loss of trust in the capitalist system and the possibility of civic unrest.

The insight underlying our approach is that governments are not the only institutions that can solve collective social and economic problems. Another type of powerful institution - the business corporation - can be brought to bear. Many of today's corporations rival nation-states in weight, influence, and reach. Collectively, they control tens of trillions of dollars in assets and affect hundreds of millions of customers, employees, and shareholders. Indeed, the corporate sector can be analogized to a kind of parallel state or shadow government that touches all our lives on a daily basis. The corporate sector can provide enormous benefits: investment returns, employment opportunities, innovative products, and tax revenues. It can also inflict great harms: environmental damage, consumer frauds, political corruption, and employee deaths and injuries.

We all have a stake in how our business corporations are governed. Yet many laypersons think of corporations as an irresistible force that helps or harms, but remains outside average citizens' control. ${ }^{1}$ As experts in corporate governance, we recognize this state of affairs need not be inevitable. Many of our current economic and social problems can be traced to the way shares in business corporations are currently owned, traded, and voted. In particular, the economic benefits of equity ownership are highly concentrated today among older, whiter, and wealthier

1. Supreme Court Justice Louis Brandeis once famously described the corporation as a “Frankenstein monster." Liggett Co. v. Lee, 288 U.S. 517, 567 (1933). 
investors. ${ }^{2}$ Shareholder influence over corporations is even more concentrated. Recognizing that their individual votes are unlikely to matter, many individual shareholders who own stocks directly do not vote their shares at all. ${ }^{3}$ Others who invest through institutions like mutual or pension funds leave the job of share voting to a handful of professional fund managers who, in turn, typically expect to keep the shares of any particular company for two years or less. ${ }^{4}$ The result is a public company sector where firms are driven to focus far more on boosting short-term share price than on pursuing long-term, sustainable, and socially beneficial corporate strategies. ${ }^{5}$

This Article outlines a plausible plan for shifting the structure of share ownership, trading, and voting to create a more democratic, sustainable, and responsible capitalism. It envisions the creation of a new type of institutional shareholder we dub the Universal Fund (Fund) and the broad distribution of ownership of shares in that Fund so that all citizensincluding young people, people of color, and less wealthy people - reap the economic benefits of the corporations that are the engines of our economy. Additionally, the plan would ensure that citizens who receive shares in the new fund have incentive to focus on long-term corporate

2. See infra text accompanying notes 36-37. In recent years, equity ownership has become even more unequal. See Jeffrey M. Jones, U.S. Stock Ownership Down Among All but Older, HigherIncome, GALLUP (May 24, 2017), http://www.gallup.com/poll/211052/stock-ownership-downamong-older-higher-income.aspx (explaining that the U.S. stock ownership rate is declining among all Americans except upper-income, older ones; in 2008, sixty-two percent of U.S. adults owned stock, whereas in 2017 , only fifty-four percent did).

3. So many shareholders are reluctant to vote that, in order to make a quorum, corporations often must hire third party proxy solicitation services to contact shareholders and try to persuade them to vote. See, e.g., Our History, GEORGESON, http://www.georgeson.com/us/about-us/our-history [https://perma.cc/XXF8-C7JV]

4. See Inv. Co. Inst., Mutual Funds And Portfolio Turnover 2 (Nov. 17, 2004), https://www.ici.org/pdf/rc_vln2.pdf [https://perma.cc/MK6V-9LAR ] (stating that in 2004, there was an average $117 \%$ portfolio turnover rate for mutual funds, implying an average holding period of less than a year); Alon Brav et. al., Hedge Fund Activism, Corporate Governance, and Firm Performance, 63 J. FIN. 1729, 1732 (2008) (explaining that the turnover rate suggests 20-month holding periods for hedge funds in the sample); see also LyNn StOUt, THE SHAREHOLDER VALUE Myth: How PutTing Shareholders First Harms InVeStors, Corporations, AND the Public 66 (2012) (stating that in 2010, average turnover for equities listed on U.S. exchanges was $300 \%$, implying a four-month average holding period).

5. See The Aspen Inst. Bus. \& Soc'y Program, Overcoming Short-Termism: A CALl for A More Responsible APPROACH to InVESTMENT AND Business MANAGEMENT (2009), https://www.aspeninstitute.org/sites/default/files/content/docs/pubs/overcome_short_state0909_0.pd $\mathrm{f}$ [https://perma.cc/W5ZT-9K2L]; THE CONFERENCE BD., IS SHORT-TERM BEHAVIOR JEOPARDIZING THE FUTURE PROSPERITY OF BUSINESS? (2015), www.wlrk.com/docs/IsShortTermBehavior JeopardizingTheFutureProsperityOfBusiness_CEOStrategicImplications.pdf [https://perma.cc/ W4FD-J2YP]; J.W. MASON, UNDERSTANDING SHORT-TERMISM: QUESTIONS AND CONSEQUENCES (2015), http://rooseveltinstitute.org/wp-content/uploads/2015/11/Understanding-Short-Termism.pdf [https://perma.cc/H8VE-TYGF]. 
sustainability and social and environmental impacts, rather than short-term share prices. Also, it would make it far easier for them to exercise an effective voice in corporate governance.

Democratic processes are important to ensuring governments serve their citizens. We show how similar benefits can be enjoyed by promoting more democracy in business corporations. Conversely, policy discussions that ignore or misunderstand the complex web of individuals, institutions, and rules that currently govern our corporate sector, at best, overlook a critical component of reform, and at worst, produce plans and proposals that are harmful. ${ }^{6}$ Corporations can generate not only private gains but public good. Indeed, engaging the full power of our business sector may be essential to meet many of our greatest challenges. It is not enough to have a democratic political system. We also need democratic capitalism. This Article suggests how to build it.

It is important to note our proposal does not rely either on market forces or government interventions. Rather, it relies on the voluntary cooperation and private ordering of free individuals using modern information technologies. Moreover, while our plan is utopian, it is also achievable. Even if initially adopted only on a small scale, it is designed to grow in size and effect over time. The primary obstacles to our plan's implementation are psychological, especially the often-unspoken beliefs that large problems cannot be solved through voluntary coordination; that humans are always and only selfish; and that anything that has not been done in the past cannot succeed in the future. Through the exercise of imagination, these obstacles can be overcome.

\section{A ThUMBNAIL SKetch OF THE PROPOSAL}

Perhaps the best way to set the stage for exploring the strengths and weaknesses of our proposal is to first present its basic features. Space constraints necessarily prevent us from presenting a detailed discussion, which we are developing in other work. ${ }^{7}$ Here, we offer a basic outline to provide the basis for exploring some of our plan's more important implications and challenges.

6. For example, in 1993, Congress amended the tax code to require public companies to tie their top executives' pay to objective performance metrics to ensure full tax deductibility - a rule change that encouraged widespread use of stock-based compensation schemes that, in turn, encouraged pathological corporate behaviors, including excessive risk-taking and fraud. Lynn A. Stout, Killing Conscience: The Unintended Behavioral Consequences of "Pay for Performance," 39 J. CORP. L. 526, 533-35 (2014).

7. With coauthor Tamara Belinfanti, we are preparing a book for Berrett-Koehler Publishers that expands upon this Article. LynN A. StOuT ET AL., Citizen CAPITAlism: How A UNIVERSAL Fund CAN PROVIDE INCOME AND INFLUENCE TO ALL (forthcoming 2019) (on file with authors). 
We have dubbed our proposal the Blueprint for Citizen Capitalism (Blueprint). Blueprint has five basic elements. First, upon reaching the age of eighteen years, all U.S. citizens ${ }^{8}$ would receive a share in a collective portfolio of securities - in effect, a share in a collective mutual fund, the Fund. As in a typical mutual fund, the Fund's shareholders would periodically receive a proportionate share of all dividends and interest payments paid to the Universal Fund Portfolio (Portfolio). ${ }^{9}$ Ideally, under our Blueprint, the Portfolio would include equity securities from a wide variety of corporations, both public and private. With this structure in mind, we call the Fund's shareholders Universal Shareholders (Shareholders). ${ }^{10}$

Second, at least initially, ${ }^{11}$ the Fund would acquire the securities in its Portfolio primarily from shares donated by high-net worth individuals and companies, for example, during public offerings. ${ }^{12} \mathrm{We}$ explore these and other funding options in greater detail later but note here such

8. Although for purposes of discussion, we propose distributing shares to U.S. citizens older than seventeen years. It is of course possible to adopt other selection criteria (e.g., citizens of all ages, all legal residents, citizens of another nation or the European Union, and so forth).

9. Our proposal embraces the spirit of the many Universal Basic Income (UBI) proposals that have been offered over the years. Such proposals date back at least to Thomas Paine's 1797 proposal for a citizen's dividend. See ThOMAs PAINE, AGRARIAn Justice (1797) (proposing that all citizens receive a "citizens dividend" as compensation for the "loss of his or her natural inheritance, by the introduction of the system of landed property"). This idea has since attracted advocates ranging from Milton Friedman to tech billionaires like Elon Musk and Mark Zuckerberg. See Sebastian Johnson, The Case for a Universal Basic Income, L.A. TIMES (June 29, 2017), http://www.latimes.com/opinion/ op-ed/la-oe-johnson-universal-basic-income-20170629-story.html [https://perma.cc/ZZV4-W9TU]. Blueprint also echoes proposals to redistribute wealth like Anne Alstott's and Bruce Ackerman's proposal for "The Stakeholder Society," outlined in their 1999 book. ANNE AlstotT \& BRUCE ACKERMAN, THE STAKEHOLDER SOCIETY (1999) (proposing that all U.S. citizens receive a onetime payment of $\$ 80,000$ upon reaching the age of 21). Similarly, Robert Hockett has proposed to redistribute all resources so that citizens are in positions of equality in an "efficient equal-opportunity republic." See Robert C. Hockett, A Jeffersonian Republic by Hamiltonian Means: Values, Constraints, and Finance in the Design of a Comprehensive and Contemporary American "Ownership Society," 79 S. CAL. L. REV. 45, 48 (2005).

10. Our concept of the Universal Shareholder should not be confused with the "universal investor" or "universal owner" label sometimes applied to large institutional investors like pension and mutual funds, which are so broadly diversified that they are more concerned with the performance of the economy as a whole than with the performance of a single company. See generally JAMES P. HAWley \& ANDREW T. Williams, The Rise of Fiduciary CAPitAlism: How Institutional INVESTORS CAN MAKE CORPORATE AMERICA MORE DEMOCRATIC (2000).

11. After some period of time and to a growing extent, Shareholders' interest in the Fund would also increase in value as the shares of deceased Shareholders revert to the Fund upon death.

12. The Fund would also hold shares of nonpublic companies to the extent these shares were contributed by either the companies themselves or by their shareholders. Leaving shares to the Fund might be an attractive option for founders of private companies who want to leave a legacy or increase the chances their companies remain in operation after their deaths. 
donations are quite likely. ${ }^{13}$ Many corporations are interested in being perceived as "good citizens," as evidenced by corporate philanthropy and the growing interest in so-called benefit corporations. ${ }^{14}$ Other corporations might view the Universal Fund as a desirable long-term shareholder. ${ }^{15}$ Similarly, many high net worth individuals have a keen interest in philanthropy, as demonstrated by the Giving Pledge recently organized by Bill Gates and Warren Buffett. By 2016, the Giving Pledge had attracted 154 signatories from sixteen countries, each of whom had pledged to give away at least half of their wealth. ${ }^{16}$

Third, the Administrators of the Universal Fund would not be entitled to any portion of the profits generated by the Fund - they would not be residual claimants. Rather, they would be passive functionaries compensated only by a fixed fee that (unlike fees in the typical mutual fund) would not be based on the Fund's performance or assets under management. ${ }^{17}$ This administrative fee should be quite low because, unlike the managers of most mutual funds today, the Administrators would not be allowed to trade securities in an effort to reap trading profits. ${ }^{18}$ Securities would exit the Portfolio only through transactions controlled by third parties (e.g., through an agreement of merger or the maturation of a

13. See infra text accompanying notes $76-80$.

14. See Suntae Kim et al., Why Companies Are Becoming B Corporations, HARV. Bus. Rev. (June 17, 2016), https://hbr.org/2016/06/why-companies-are-becoming-b-corporations [https://perma. cc/XUG5-PNQ9]; see also CR's 100 Best Corporate Citizens 2017, CORP. RESP. MAG., Mar.-Apr. 2017, http://www.thecro.com/wp-content/uploads/2017/05/CR_100Bestpages_digitalR.pdf [https:// perma.cc/5HNW-MZ74]; Giving USA 2017 Infographic, GIVING USA, https://givingusa.org/see-thenumbers-giving-usa-2017-infographic/ [https://perma.cc/3KCF-5G8J]_(noting that giving from corporations amounted to $\$ 18.55$ billion in 2016). Corporate philanthropy can also attract substantial positive attention.

15. To the extent that corporate directors and managers feel pressure to abandon desirable strategies in order to placate short term shareholders, see supra note 5 , they might prefer to have a significant block of shares held by the Fund, an intrinsically long-term investor whose Administrators and Shareholders cannot buy or sell. See infra text accompanying notes 50-58.

16. Laura Lorenzetti, 17 More Billionaires Join Buffett and Gates' Giving Pledge this Year, FORTUNE (June 1, 2016), http://fortune.com/2016/06/01/giving-pledge-new-members-2016/ [https:// perma.cc/TU7P-VT8R].

17. If Administrators were compensated according to the size or performance of the Fund, this would create a perverse incentive for the Administrators to try to inflate the Portfolio's reported market value, e.g., by withholding or making it difficult for Shareholders to receive dividends. It could also result in Administrators being rewarded or punished for market shifts beyond their control.

18. Administrative fees for the Fund will resemble fees paid to "passively managed" or "index" funds, which generally are extremely low. For example, where the average actively managed stock fund charges expenses of $1.34 \%$ of assets managed annually, Vanguard and Schwab offer "ETF" equity funds that charge annual fees of only $0.05-0.03 \%$. Heather Long, The Best Cheap Investment Funds, CNN MONEY (June 6, 2016), http://money.cnn.com/2016/06/06/investing/invest-in-fundswith-low-fees/index.html [https://perma.cc/WJK4-DKXW]. 
bond). ${ }^{19}$ The Administrators' job would be just that-passive administration, including maintaining a list of Shareholders, distributing dividends, and so forth.

Fourth, Shareholders in the Fund would not be allowed to sell, hypothecate, or bequeath their shares. ${ }^{20}$ Shares would be held throughout the Shareholders' lives, and upon their deaths, their interests in the Fund would revert to the Fund itself (thus, marginally increasing the value of all other Shareholders' interests, just as the issuance of new shares to new Shareholders would marginally dilute all other Shareholders' interests). The sole economic benefit enjoyed by Shareholders by virtue of their interest in the Fund would be a proportionate interest in the dividends and interest the Fund received from its portfolio securities. This economic interest makes Shareholders, of necessity, long-term shareholders. ${ }^{21}$ Rational Shareholders would anticipate that as long as the companies whose shares and bonds were held by the Fund pay dividends and interest, they will receive a stream of income. This income stream would not be guaranteed. Rather, it would be determined by the performance and distribution policies of the underlying corporations whose securities were held in the Portfolio.

Finally, unlike either the typical mutual fund, or the typical wealth redistribution or basic income proposal, ${ }^{22}$ under Blueprint Shareholders would receive not only a proportionate economic right to dividends and interest paid into the Portfolio but also a proportionate political right to direct how Administrators vote the equity securities held in the Portfolio in the annual and special shareholders' meetings. ${ }^{23}$ The governance of

19. The cash generated from such transactions could be used by the Administrators to purchase additional equity securities according to some automatic rule, such as "buy more stocks in the same proportions as those already found in the Portfolio or "buy the stocks in the S\&P index."

20. Universal Fund Share ownership would thus become an "inalienable right." See generally Guido Calabresi \& A. Douglas Melamed, Property Rules, Liability Rules, and Inalienability: One View of the Cathedral, 85 HARV. L. REV. 1089 (1972). Restrictions on Shareholders' sale, bequeathing, or hypothecation of shares could be enforced by making such transactions legally invalid. Cf. Lynn A. Stout, Why the Law Hates Speculators: Regulation and Private Ordering in the Market for OTC Derivatives, 48 DuKE L.J. 701, 713-21 (1999) (discussing common law rule making derivative contracts legally unenforceable).

21. Although Shareholders nearing the end of their life expectancy may be more short-term oriented (for example, preferring that companies adopt overly generous dividend policies), their interests will be counterbalanced by younger Shareholders who prefer that corporations invest optimally for future returns. This dynamic is different from the incentives of today's shareholders, who typically hold shares for two years or less. See supra note 4.

22. See supra note 9.

23. Today, mutual funds generally do not offer their investors the option of directing how the shares in the fund portfolio should be voted, likely because it is not rational for such investors to want to vote. See infra note 86 (discussing "rational apathy"). 
companies in the Portfolio is a common good, and the transaction costs associated with becoming informed and issuing instructions would deter most Shareholders from giving voting instructions directly as individuals. However, Shareholders could delegate their voting rights to shareholder "proxy service" firms, similar to those that exist today to develop voting guidelines and cast delegated votes for institutional investors (e.g., Glass Lewis and Institutional Shareholder Services (ISS)). ${ }^{24}$ Blueprint would create incentives to develop proxy services that cater to the long-term, diversified interests of Shareholders because it would mandate that the cost of these firms' services (typically quite small) ${ }^{25}$ be borne by the Fund rather than by individual Shareholders. Such an arrangement would promote the development of new proxy services that compete for Shareholders' patronage on the basis of the quality of voting guidelines and services, rather than low cost. ${ }^{26}$ Thus, unlike retail investors today, Shareholders could end up exercising significant collective influence over how the companies held in the Portfolio are governed.

This brief Introduction, laying out the bare bones of our proposal, has likely raised questions in the minds of many readers. We hope to answer many of them in Parts I and II (below), which offer a more detailed discussion of how Blueprint can address a range of social concerns and discuss possible critiques and challenges. Due to space constraints and the inevitable uncertainty associated with designing complex new institutions, it is not possible in these pages to describe every possible element of the Fund and the accompanying new shareholder proxy services envisioned by Blueprint. Nor can we provide definitive answers here to every possible policy choice or question Blueprint poses. We hope simply to persuade most readers that such details are worthy of being debated and determined in future work and to offer a promising new direction for using voluntary private ordering and corporate governance to address, if not entirely

24. See generally U.S. GOV'T ACCOUNTABILITy OfFICE, GAO-17-47, Corporate SHAREHOlder MEETINGS: ProXy AdVISORY Firms' ROLE IN VOTING AND CORPORATE GOVERNANCE PRACTICES (2016), http://www.gao.gov/assets/690/681050.pdf [https://perma.cc/ 738C-AT5Q]; Lynn A. Stout, Guest Column, Why Should ISS Be the New Master of the Corporate Governance Universe?, DOW JONES CORP. GOVERNANCE, Jan. 4, 2006.

25. Although mutual funds do not break out the fees-they pay proxy services in their SEC filings - necessarily, the fees must be significantly less than the total annual administrative expenses incurred by index funds, which can be as little as $0.03-0.05 \%$ of assets. See supra note 18 .

26. Mutual funds feel pressured by federal regulations to use proxy services but remain rationally indifferent to the quality of their voting guidelines. They therefore prefer to select a proxy service that has the lowest possible cost and that other funds use (thus, providing regulatory "cover"). Moreover, to the extent that actively managed mutual funds use proxy services, their relatively short holding drives them to prefer proxy service guidelines that emphasize short-term share price performance. See generally Tamara C. Belinfanti, The Proxy Advisory and Corporate Governance Industry: The Case for Increased Oversight and Control, 14 STAN. J.L. BuS. \& FIN. 384 (2009); Stout, supra note 24. 
resolve, social and economic problems that have proven resistant to market forces and government regulation.

\section{PROBLEMS ADDRESSED}

To understand the potential power of Blueprint, it is useful to begin by recognizing the wide range of social and economic problems it can help address. These problems include - but importantly, are not limited to - the inequality and income insecurity that typical wealth redistribution and basic income proposals focus on. Thus, we briefly describe below seven economic and social phenomena that are widely recognized today in the United States as problems in need of a remedy. They are: rising inequality, a persistent racial divide in wealth and equity ownership, increasing poverty and income insecurity, a need for more innovation and investment in the future, the externalization of many costs of corporate activity, the corrupting influence of corporate money in politics, and rising civic discontent and related "soft" social ills.

\section{A. Rising Inequality}

There is considerable debate today over wealth and income inequality, which appears to be increasing in the United States. For example, the share of wealth held by the top $0.1 \%$ of wealth holders increased from seven percent in 1978 to twenty-two percent by $2012 .{ }^{27}$

Many informed observers believe inequality is likely to worsen in the future. Thomas Piketty has famously argued in his best-selling book, Capital in the Twenty-First Century, that returns to capital now exceed economic growth rates and further suggested reasons why asset holders' incomes may exceed wage earners' even more in the future. ${ }^{28} \mathrm{He}$ has estimated that the top ten percent of income earners saw their share of national income increase from thirty to thirty-five percent to forty-five to fifty percent between the 1970 s and the 2000 s, and if this trend continues, the top decile will capture sixty percent by $2030 .{ }^{29}$ Commentators have identified other trends likely to worsen inequality, including: the

27. Emmanuel Saez \& Gabriel Zucman, Wealth Inequality in the United States Since 1913: Evidence From Capitalized Income Tax Data, 131 Q.J. ECON. 519, 520 (2016). Inequality is also endemic at the global level; the net worth of the eight richest individuals, six of whom are American, now equals the wealth of the bottom half of the remaining human population. OXFAM INT'L, AN ECONOMY FOR THE 99\%: IT'S TIME TO BUILD A HUMAN ECONOMY THAT BENEFITS EVERYONE, NOT Just the PRIVILEgED Few 2, 10 (2017), https://www.oxfam.org/sites/www.oxfam.org/files/file_ attachments/bp-economy-for-99-percent-160117-en.pdf [https://perma.cc/U2GX-DMZA].

28. Thomas PiketTy, Capital in the Twenty-First Century 22-27, 220-22, 350-60 (Arthur Goldhammer trans., President \& Fellows Harv. Coll. 2014).

29. Id. at 294 . 
elimination of many jobs through automation, ${ }^{30}$ the increasing concentration of stock ownership in public companies, ${ }^{31}$ the recent pattern of public companies disappearing to be replaced by private companies, ${ }^{32}$ and the creation of massive fortunes that allow the ultra-wealthy to acquire still more wealth through corruption and political rent-seeking. ${ }^{33}$

Blueprint works to temper inequality by redistributing ownership of equity more equally; thus, providing additional ongoing income that contributes relatively more to the incomes of lower earners. ${ }^{34}$ Although considerable inequality would persist (as is true under most wealth redistribution and basic income proposals), Blueprint has one additional and highly significant advantage over other proposals. That advantage is: Blueprint does not require government intervention or coercive taxation, whether of wealth, incomes, or robots that replace human workers. ${ }^{35}$ Rather, Blueprint tempers inequality through the voluntary actions of individuals and corporations, and eventually, the return of shares to the Fund upon the deaths of individual Shareholders.

\section{B. Demographic Differences in Equity Ownership}

Wealth and income are not only distributed unequally today; this inequality follows racial and generational patterns, especially in equity ownership. For example, in 2011, the median financial wealth (checking and retirement accounts) of African-Americans was only \$200, while that

30. See infra text accompanying notes 37 and 41.

31. See GALLUP, supra note 2 (stating that stock ownership declined from sixty-two percent to fifty-four percent from financial crisis).

32. See Gerald F. Davis, The Vanishing American Corporation: Navigating the HAZARDS OF A NEW ECONOMY 15-17 (2016) (stating that domestic companies listed on U.S. exchanges declined from more than 8000 in 1996 to just over 4000 in 2012); Bob Bryan, There Are Nowhere Near as Many Public Companies in the U.S. as There Should Be, BUS. INSIDER (July 5, 2015 8:27 AM), www.businessinsider.com/us-has-too-few-publicly-listed-companies-2015-6 [https:// perma.cc/2KD4-44BB] (citing a study concluding that U.S. listings were declining while listings elsewhere were increasing, and that more than half of the "listing gap" was attributable to new companies declining to list).

33. See Moses Naim, The Problem with Piketty's Inequality Formula, ATLANTIC (May 27, 2014), https://www.theatlantic.com/international/archive/2014/05/the-problem-with-pikettysinequality-formula/371653/ [https://perma.cc/23PN-CHTL].

34. When wealthy individuals and less wealthy individuals receive equal dividends, the relative benefits are greater for the less wealthy.

35. Thomas Piketty advocates for a progressive annual tax on capital. PIKKETY, supra note 28 , at 572. Tech billionaire, Bill Gates, has proposed taxing robots that replace human workers. I, Taxpayer, ECONOMIST, Feb. 25, 2017, at 72. See generally James K. Boyce \& Peter Barnes, How to Pay for Universal Basic Income, EvONOMICS (Nov. 28, 2016), http://evonomics.com/how-to-pay-foruniversal-basic-income/ [https://perma.cc/5KSK-MY7E]. 
of whites was $\$ 23,000 .{ }^{36}$ Fully thirty-eight percent of African-Americans had no financial assets, compared to only fourteen percent of whites. Younger citizens also are underrepresented in equity markets. Where sixty-two percent of individuals ages fifty to sixty-four hold stocks, only thirty-one percent of individuals ages eighteen to twenty-nine do, and the percentage of eighteen to twenty-nine-year-olds who invest is declining. ${ }^{37}$

Demographic differences in equity ownership raise several troubling issues beyond the overarching issue of socioeconomic inequality. Racial gaps in equity ownership can be attributed in large part to the persisting effects of past racialized policies (e.g., slavery, segregation, exclusionary laws) as well as present disadvantages (e.g., failing schools, housing and employment discrimination). Such inequality of opportunity raises important questions of justice and morality and creates realistic perceptions of relative disadvantage that contribute to racial tension and civil unrest. It also poses economic challenges: as the United States becomes more racially diverse, it becomes more important to ensure that all segments of our population have the resources needed to become productive citizens and consumers. Age-based differences also raise problems. For example, older shareholders are likely to prefer companies that pursue short-term goals rather than make long-term investments, and retirees may be less concerned about how companies treat employees than younger shareholders who are still in the workforce. Yet, to the extent individual shareholders participate in corporate governance, it is older, whiter (and of course wealthier) ${ }^{38}$ citizens who exercise the most influence over companies.

36. Rebecca Tippett et al., Ctr. For Global Policy Solutions, Beyond Broke: Why Closing the Racial Wealth Gap is a Priority For National Economic Security 2 (May 2014), http://globalpolicysolutions.org/wp-content/uploads/2014/04/BeyondBroke_Exec_Summary. pdf [https://perma.cc/L27M-6Q7K]. In 2013, the percentage of non-Hispanic black or Hispanic households owning stocks was $36-37 \%$, whereas the percentage of non-Hispanic white households owning stocks was $60 \%$. GALLUP, supra note 2 . The mean value of stock holdings for households with holdings was $\$ 99,200$ for non-Hispanic black or Hispanic households, and $\$ 315,400$ for white, nonHispanic households. GALLUP, supra note 2.

37. GALLUP, supra note 2. In 2013, the mean value of stock holdings for households whose head was less than thirty-five years old amounted to $\$ 42,700$. For households whose head was between sixty-five and seventy-four, the mean amounted to $\$ 552,200$. U.S. FED RESERVE, SURVEY OF CONSUMER FINANCES CHARTBOOK (2013) [hereinafter SCF]. While age-based differences in equity ownership can be traced in part to the investing life cycle (savings tend to accumulate overtime), to the extent older citizens participate more in corporate governance, they exercise greater influence over corporate behavior.

38. In 2013 , only $11.4 \%$ of households in the bottom twenty percent for income held stocks, whereas ninety-three percent of households in the top decile for income held stocks. SFC, supra note 37 , at 510 . Moreover, only $15.8 \%$ of households in the bottom twenty-five percent for net worth held stocks, whereas $91.6 \%$ of households in the top decile for net worth held stocks. Id. at 540 . The mean value of stock holdings for households with holdings in the bottom twenty-five percent of net worth 
While hardly a definitive solution, Blueprint would counteract these patterns by redistributing both investment returns from, and control over, the corporate sector. This would allow our corporations to better benefit all our citizens. The result would be more justice, less racial tension, and a brighter future.

\section{Increasing Poverty and Income Insecurity}

In addition to rising inequality and demographic differences in equity markets, the United States has also seen increasing poverty in recent years. In 2014, the U.S. poverty rate was four percent higher than it had been four decades earlier. ${ }^{39}$ This trend has likely been driven by many of the same factors that contribute to rising inequality. ${ }^{40}$ For example, some estimates predict that automation could eliminate almost half of all jobs in the near future. ${ }^{41}$ Such developments threaten not only more poverty but also greater income insecurity - insecurity worsened by the erosion of the social safety net provided by family and community ties and by social insurance programs like Medicare and Social Security. ${ }^{42}$

It is worth noting that inequality and poverty have their own negative macroeconomic effects. For example, poverty and economic stress make it difficult for individuals to invest in their own human capital. ${ }^{43}$ And a robust literature shows that income inequality is harmful to economic growth. ${ }^{44}$

Blueprint would help address these problems, albeit imperfectly. This is because it would give Shareholders a variable income subsidy determined by the dividends received by the Portfolio. Although it would not provide a guaranteed minimum level of income, this is an advantage

was $\$ 6,400$, whereas the mean value of stock holdings for households with holdings in the top decile was $\$ 1,161,700$. Id. at 542 .

39. Anthony B. Atkinson, How to Spread the Wealth: Practical Policies for Reducing Inequality, 95 FOREIGN AFF. 29, 29 (2016).

40. See supra text accompanying notes $23-35$.

41. McKinsey \& Co., A Future That Works: Automation Employment and Productivity 4 (2017); Carl Benedikt Frey \& Michael A. Osborne, The Future of Employment: How Susceptible Are Jobs to Computerisation?, 114 TECH. ForeCASTING \& SOC. ChANGE 254, 265 (2017).

42. See Robert Putnam, Bowling Alone: The Collapse and Revival of American COMMUNITY (2000) (discussing declines in community support and activity); Soc. Sec. \& Medicare Bd. of Tr., A Summary of the 2017 Annual Reports, Soc. SEC. ADMIN., https://www.ssa.gov/ oact/trsum/ [https://perma.cc/N5P7-LG4J ] ("Both Social Security and Medicare face long-term financing shortfalls.").

43. Acquiring education and skills takes time and money that are generally not available to those struggling for subsistence.

44. See Alberto Alesina \& Dani Rodrik, Distributive Politics and Economic Growth, 109 Q. J. ECON. 465, 478-84 (1994); Torsten Persson \& Guido Tabellini, Is Inequality Harmful for Growth?, 84 AM. ECON. REv. 600, 607-08 (1994). 
to the extent we are concerned that a guaranteed income might create too great a disincentive to work and invest in one's own human capital. ${ }^{45}$

\section{Need for More Innovation and Investment in the Future}

Unlike proprietorships and most partnerships, corporations are perpetual entities. ${ }^{46}$ Add in the corporate characteristics of asset lock-in, limited liability, delegated management, and transferable shares, and corporations become institutions particularly well-suited to making longterm, large-scale, uncertain investments, such as investments in major infrastructure projects and in the invention and development of new and transformative products and services. ${ }^{47}$ Corporations were critical to the development of (to give just a few examples) the railroads, the electrical grid, and the internet. Today, they are developing cleaner energy sources, self-driving cars, and cures for cancer. ${ }^{48}$

Such corporate innovations and investments provide a myriad of economic and social benefits, including not only financial returns for stock and bondholders but also employment opportunities, quality products, tax revenues for governments, and transformative technologies that contribute to human well-being. Moreover, those benefits contribute to the welfare of not only present but future generations. New York City's residents still draw power from the electrical grid developed by the Edison Illuminating Company, the corporate precursor to today's Consolidated Edison. ${ }^{49}$

However, there is reason to fear that recent changes in shareholding and share voting patterns are degrading corporations' ability and willingness to devote resources to developing such critical long-term projects. ${ }^{50}$ Tax incentives have created large institutional investors like pension and mutual funds; reduced trading costs have made it possible for them to seek profits from short-term trading; and the U.S. Securities and Exchange Commission's (SEC) rules have given them power to influence

45. See Eduardo Porter, A Universal Basic Income Is a Poor Tool to Fight Poverty, N.Y. TiMES (May 31, 2016), https://www.nytimes.com/2016/06/01/business/economy/universal-basic-incomepoverty.html (discussing disincentives to work).

46. See Andrew A. Schwartz, The Perpetual Corporation, 80 Geo. WASH. L. Rev. 764, 766, (2012); Lynn A. Stout, The Corporation as Time Machine: Intergenerational Equity, Intergenerational Efficiency, and the Corporate Form, 38 SEATTLE U. L. REV. 685, 694-98 (2015).

47. Stout, supra note 46 , at 687-89.

48. Id. at $699,702-03$.

49. The History of Alternating Current: The History of Electrification, EDISON TECH CTR., http://www.edisontechcenter.org/HistElectPowTrans.html [https://perma.cc/E5MA-ZYWV].

50. Stout, supra note 46, at 708-21; see also supra note 5. 
corporate behavior. ${ }^{51}$ The result — many influential academics, business leaders, and policy research institutes have argued - is a large and powerful shareholder class with perverse incentives to pressure managers to pursue short-term financial results while neglecting long-term investments. ${ }^{52}$ For example, in the $1950 \mathrm{~s}$, American corporations retained sixty percent of their profits for research and development (R\&D); today they retain less than ten percent. ${ }^{53}$ Rather than reinvesting, American corporations buy back their own stock and reduce "expenses" like payroll and $R \& D$ to artificially boost earnings per share. ${ }^{54}$ The great American corporate research labs of the mid- to late-20th century are disappearing as employees are cut and the focus is shifted from pure research to modest projects with immediate profit potential. ${ }^{55}$

Blueprint would help address this problem by creating a new, powerful, and inherently long-term institutional investor, the Fund. The Administrators cannot trade, and the Shareholders cannot sell or hypothecate their shares. Neither have reason to focus on the share prices of the companies in the Portfolio. ${ }^{56}$ Indeed, to the extent Blueprint gives Shareholders a bigger role in corporate governance (which they will typically exercise by selecting a proxy service whose voting guidelines

51. See, e.g., Edward B. Rock, Adapting to the New Shareholder-Centric Reality, 161 U. PA. L. REV. 1907, 1922-23 (2013). See generally Lynn A. Stout, The Toxic Side Effects of Shareholder Primacy, 161 U. PA. L. ReV. 2003 (2013).

52. See, e.g., supra note 51. The perverse incentives arise from the fact that while most individuals want to make long-term, diversified investments not only in different equities but also in bonds, real estate, and their own human capital, the portfolio managers who make trading decisions for mutual, pension, and hedge funds are judged only on their short-term performance and are relatively undiversified. See STOUT, supra note 4, at 50-51 (describing investor "Tragedy of the Commons"), 63-94 (describing why fund managers are poor representatives of individual investors' interests). See generally Leo E. Strine, Jr., Can We Do Better by Ordinary Investors? A Pragmatic Reaction to the Dueling Ideological Mythologists of Corporate Law, 114 COLUM. L. REV. 449 (2014).

53. David Ciepley, Beyond Public and Private: Toward a Political Theory of the Corporation, 107 Am. Pol. Sci. Rev. 139, 148-49 (2013) (citing Jack B. Jacobs, 'Patient Capital': Can Delaware Corporate Law Help Revive It?, 4 WASH. \& LEE L. REV. 1645, 1645-64 (2011)); see also Robert J. Gordon, Policy Insight No. 63: Is U.S. Economic Growth Over? Faltering Innovation Confronts the Six Headwinds, CTR. ECON. POL'Y RESEARCH (Sept. 2012), http://cepr.org/sites/default/ files/policy_insights/PolicyInsight63.pdf [https://perma.cc/2AZC-QDTC].

54. William Lazonick, Profits Without Prosperity, HARV. Bus. ReV., Sept. 2014, https://hbr.org/ 2014/09/profits-without-prosperity [https://perma.cc/WC6Y-CZQG].

55. Chris Matthews, The Death of American Research and Development, ForTunE (Dec. 20, 2015), http://fortune.com/2015/12/21/death-american-research-and-development/ [https://perma.cc/ Q5T6-UXGZ].

56. There remains the problem of executive compensation schemes that give company executives such a focus. See supra text accompanying note 6; see also MichaEl B. DORFF, INDISPENSABLE AND OTHER MYTHS: WHY THE CEO PAY EXPERIMENT FAILED AND HOW TO FIX IT 123-49 (2014). If Blueprint succeeded in giving Shareholders, who are intrinsically long-term, a greater role in corporate governance, they might be able to reform such executive compensation schemes. 
suit their preferences), they counterbalance the power of short-term investors. And, while a minority of older Shareholders nearing the end of their lifespans may favor corporate policies that promote too-high dividends or short-term results, ${ }^{57}$ most Shareholders are younger and have decades of investment returns ahead of them. They have incentive to favor efficient reinvestment for the future over immediate payouts. ${ }^{58}$ The result is the creation and empowerment of a class of Shareholders that has, on average, a much longer investment time horizon than the institutions that currently exercise the loudest voice in corporate governance.

Finally, it is also possible that Blueprint can encourage more innovation, entrepreneurship, and creativity among individual Shareholders themselves. This is because it can reduce individuals' immediate economic insecurity, giving them "breathing room" and resources to take business risks and invest in their own human capital. ${ }^{59}$

\section{E. Externalization of Costs and Benefits of Corporate Activity}

Due to their great size, limited liability, and the inevitable imperfections of tort law and government regulation, business corporations have immense capacity to make third parties bear some of the costs of their activity while retaining all the profits. (Joel Bakan has famously described corporations as "externalizing machines.") ${ }^{60}$ Examples of such external costs from corporate activity are legion, including environmental pollution, defective goods, employee deaths and injuries, high-risk/high-yield activities that put the financial system at risk, and pumping carbon into the atmosphere with resulting climate change.

Although less-well recognized (albeit arguably as or more important), social benefits are another external effect of corporate activity. In the process of generating investment returns for shareholders, corporations also produce jobs for employees, products for consumers, tax revenues for governments, a skilled, socialized workforce for other

57. On the other hand, there is evidence that people tend to become more altruistic and prosocial as they age, suggesting that older shareholders may altruistically remain interested in promoting longterm corporate investments that benefit younger generations. See generally Janelle N. Beadle et al., Aging, Empathy, and Prosociality, 70 J. Gerontology Series B: Psychol. SCI. \& Soc. SCI. 213 (2015).

58. Although Shareholders may be somewhat myopic, it is unrealistic to believe they would be more focused on the short term than fund managers whose professional success often depends on the next quarter's portfolio returns.

59. Scott Santens, Universal Basic Income Accelerates Innovation by Reducing Our Fear of Failure, Evonomics (Feb. 12, 2017), http://evonomics.com/universal-basic-income-acceleratesinnovation-reducing-fear-failure/ [https://perma.cc/8WKE-8EF8].

60. Joel Bakan, The Corporation: The Pathological Pursuit of Profit and Power 70 (2005) (titling chapter "The Externalizing Machine"). 
employers, and critical new infrastructure and technologies for the broader society. As noted in the previous section, these social goods enormously benefit not only present but also future generations-just as some corporate external costs, like contributing to climate change and environmental degradation, harm future generations.

Unfortunately, when corporations are managed to maximize only profits or "shareholder value," they ignore both external costs imposed and external benefits foregone by their activity. And today's public business corporations face considerable pressure to maximize profits and/or shareholder value, much of it generated by institutional shareholders like pension, mutual, and hedge funds. ${ }^{61}$ The resulting "psychopathic" corporate behavior (as Bakan puts it) ${ }^{62}$ emphasizes short-term financial results while ignoring ethics and the welfare of stakeholders and future generations. This approach fails to serve most shareholders, because they are not only shareholders; they are also consumers, employees, taxpayers, organisms that must live in the environment, and ethical beings who often care (to at least some degree) about others' welfare, including the welfare of those who come after them. ${ }^{63}$ From the Shareholders' perspective, "external" corporate costs and benefits are not really external at all.

Blueprint addresses the corporate externalities problem by giving Shareholders a greater role in corporate governance. The Shareholders would be able to aggregate their voting power through new Shareholderoriented proxy services similar to those that already exist to serve shortterm institutional investors. As a result, Shareholders could collectively and effectively use their voting power to shift corporations toward better serving society and Shareholders themselves, countering the short-term shareholder pressures that currently drive corporate managers to maximize profits at the expense of public health, public safety, and the planet.

\section{F. Corporate Money in Politics}

In addition to a general concern about the corporate externalities problem, in the wake of the U.S. Supreme Court's decision in Citizens United, there has been increasing debate on the role of corporate money in politics. ${ }^{64}$ To simplify the problem, corporations can allocate resources to socially beneficial activities like producing quality goods and services,

61. See supra notes 4-5. Additional pressure comes from "pay for performance" executive compensation schemes that emphasize share price or profits. See generally Stout, supra note 6.

62. BAKAN, supra note 60 , at 60 .

63. It does, however, serve fund managers, private equity partners, and CEOs whose pay is driven by stock price performance, as they are much less diversified than shareholders and their greater wealth also allows them to escape many of the external costs from corporate activity.

64. See Citizens United v. Fed. Election Comm’n, 558 U.S. 310, 339-40 (2010). 
generating employment opportunities, or even paying taxes. They can also, however, devote resources to capturing the political system for what economists call "rent-seeking." 65 One example would be devoting resources to evading socially beneficial regulation or taxation. Between 1998 and 2008, for example, bank interests spent \$3.4 billion lobbying the U.S. government to deregulate derivatives, ${ }^{66}$ increasing systemic risk and contributing to the 2008 financial crisis.

Business corporations can influence the political system through campaign donations, lobbying, "revolving door" hiring, and public relations. Individuals can do the same, of course, but corporations' great wealth and concentration allows them to exercise outsize influence. This may not be a problem when corporations promote rules that serve the broader society. Corporate political influence becomes problematic, however, when it is used for rent-seeking. Further, rent-seeking is more likely when corporate political activity is opaque since customers, employees, investors, and citizens cannot detect or respond to it.

Through Blueprint, Shareholders would be empowered to collectively address the issue of corporate money in politics. They could do this by delegating their votes in corporate elections to proxy advisory services whose guidelines support greater disclosure of corporate political activities. Better corporate disclosure surrounding political activity would allow citizens and Shareholders alike to better police against corporate rent-seeking, and ensure that corporate political activity is directed to more socially beneficial ends. ${ }^{67}$

\section{G. "Softer" Social Ills}

In addition to the relatively quantifiable problems described above, Blueprint can help address other, "softer" social ills that have attracted recent attention. One such ill is declining public support for capitalism in general and for the corporate sector in particular.

65. See David W. Barnes \& Lynn A. Stout, Cases and Materials on Law and ECONOMICS 476-91 (1992) (discussing rent-seeking); Richard L. Hasen, Lobbying, Rent-Seeking, and the Constitution, 64 STAN. L. REv. 191, 228-30 (2012). On the misuse of resources for rent-seeking instead of for productive activity, see generally William J. Baumol, Entrepreneurship: Productive, Unproductive, and Destructive, 98 J. POL. ECON. 893 (1990).

66. Helen Burley \& Olivier Hoedeman, The Best Influence Money Can Buy, NEw InTERnATIONAList, Jan. 1, 2011; WALl St. WATCH, EXeCutive Summary 15, http://www.wallstreetwatch.org/reports/executive_summary.pdf [https://perma.cc/CCF2-XHZP].

67. Indeed, corporations may have more incentive to promote transparency than politicians do. Fred McChesney has argued persuasively that politicians often solicit campaign contributions from corporations by threatening regulatory action in what amounts to a form of extortion. See generally Fred S. McChesney, Money for Nothing: Politicians, Rent Extraction, and Political EXTORTION (1997). 
Surveys show that public trust in business has declined significantly. From 1977 until 1990, twenty to thirty-two percent of survey respondents reported having "quite a lot" or "a great deal" of confidence in big business, while between 2008 and 2017 these figures declined to only sixteen to twenty-two percent. ${ }^{68}$ Younger generations in particular may be losing faith in capitalism; recent polls show more young Americans disapproving of capitalism than supporting it. ${ }^{69}$ Some might applaud such shifts in public attitude. But to the extent a thriving business sector and strong corporations contribute to social welfare, reduced support for business translates to lost progress and prosperity. Blueprint can help build public support for capitalism and the corporate sector by allowing the vast majority of the population to benefit from, have a stake in, and influence business corporations. It would also increase perceptions that corporations operate in an ethical and socially beneficial fashion.

Another potential problem that could be tempered by Blueprint is the widespread loss of a sense of personal agency and purpose that could result if automation continues to eliminate greater and greater numbers of jobs. ${ }^{70}$ Many Shareholders might choose not to direct the Administrators on how to vote their proportionate share of the equities in the Portfolio. However, many others would likely elect to use a proxy service to vote their shares, and a few might seek to become directly involved in creating voting guidelines. This citizen involvement in corporate governance can, at least to some extent, substitute for the sense of agency and purpose provided by employment. Further, it can promote greater social cohesion and civic engagement by promoting a sense of "in-group" membership among

68. Confidence in Institutions, GALLuP NEWS, http://news.gallup.com/poll/1597/confidenceinstitutions.aspx.

69. A 2016 Harvard poll of young adults (eighteen to twenty-nine years old) nationwide found that fifty-one percent do not support capitalism while only forty-two percent support it. A few years earlier, a 2011 poll of the same demographic by the Pew Research Center found that forty-six percent had positive views of capitalism and $47 \%$ had negative views. Max Ehrenfreund, A Majority of Millennials Now Reject Capitalism, Poll Shows, WASH. POST (Apr. 26, 2016), https:/www.washingtonpost.com/news/wonk/wp/2016/04/26/a-majority-of-millennials-now-rejectcapitalism-poll-shows/?utm term=.4f91019c2ee1 [https://perma.cc/T5NY-QRRD].

70. See The Dalai Lama \& Arthur C. Brooks, Dalai Lama: Behind Our Anxiety, the Fear of Being Unneeded, N.Y. TIMES (Nov. 4 2016), https://www.nytimes.com/2016/11/04/opinion/dalailama-behind-our-anxiety-the-fear-of-being-unneeded.html (arguing that unemployment contributes to a debilitating sense of a lack of purpose in life, as well as financial stress); see also Eduardo Porter, $A$ Universal Basic Income Is a Poor Tool to Fight Poverty, N.Y. TIMES (May 31, 2016), https://www.nytimes.com/2016/06/01/business/economy/universal-basic-income-poverty.html?_r=2 (arguing that employment provides opportunities for personal progress, self-discipline, and purpose). 
Shareholders. ${ }^{71}$ This collective sense of community, especially when combined with increased equality, economic security, and public support for capitalism, pays additional dividends by reducing the likelihood of destructive civic unrest. ${ }^{72}$

Finally, Blueprint promotes intergenerational equity and progress. The present-day corporate emphasis on maximizing "shareholder value" tends to focus corporate managers on immediate financial results, whether measured by accounting profits or by share price. This can cause corporations to pass up investment opportunities that would generate primarily long-term returns, for example, by declining to pursue the kind of fundamental research that leads to transformative innovations that benefit future generations. ${ }^{73}$ Similarly, a focus on immediate financial returns tempts corporate managers to ignore social costs likely to be incurred primarily in the future, such as the costs of climate change. By creating a class of empowered long-term Shareholders, Blueprint would help corporations invest in the kind of innovation that benefits future generations. It would also allow prosocial Shareholders to better express their preferences for controlling generation-spanning external costs like pollution and climate change.

\section{Challenges AND CRITIQUES}

Space constraints preclude our addressing every possible objection or obstacle to implementing Blueprint here. Instead, we discuss the most obvious issues: adequacy and sources of funding; agency costs imposed by Fund Administrators; reduced informational efficiency in stock pricing; practical obstacles to Shareholder voting; and the risk of irrational or antisocial Shareholder preferences.

\section{A. Adequacy and Sources of Funding}

As an initial matter, the size of the Portfolio determines the degree to which Blueprint promotes democratic capitalism but does not change the

71. See Lynn Stout, Cultivating Conscience: How Good Laws Make Good People 145 47, 238-42 (2011) (discussing how a sense of common fate promotes perceptions of in-group identity that foster trust, trustworthiness, and other prosocial behaviors).

72. Alberto Alesina \& Roberto Perotti, Income Distribution, Political Instability, and Investment, 40 EUR. ECON. REV. 1203, 1217-19 (1996) (reporting that income inequality increases socio-political instability). In the 2013 World of Work report, the International Labour Organization warned that joblessness, especially long-term unemployment, has fueled social unrest, especially in advanced economies. INT'L LABOUR ORG., WORLD OF WORK REPORT 2013: REPAIRING THE ECONOMIC AND SOCIAL FABRIC 14-16 (2013), http://www.ilo.org/wcmsp5/groups/public/--dgreports/---dcomm/documents/publication/wcms_214476.pdf [https://perma.cc/R386-PMFM].

73. See generally Stout, supra note 46. 
direction of its effects. The only question is whether the Blueprint would have more, or less, impact.

For the past five years, U.S. corporate profits have averaged about $\$ 1.6$ trillion annually. ${ }^{74}$ There are an estimated 227 million U.S. citizens over the age of eighteen. ${ }^{75}$ This means corporate profits per adult citizen average over $\$ 7,000$ annually. The impact of Blueprint, in terms of the significance of the income to and influence exercised by Shareholders, depends on how large a percentage of outstanding corporate securities are held by the Fund. For example, if the Fund held ten percent of all equities, each Shareholder's representative interest in corporate profits would amount to about $\$ 700$ annually. The larger the share of equities held by the Fund, the greater Blueprint's impact.

There are several ways the Fund could amass a significant Portfolio relatively quickly. First, ultra-high-net worth individuals are a significant potential source of portfolio donations. The upper decile of wealth-holders own more than eighty percent of all stocks, ${ }^{76}$ and eventually their fortunes must change hands; it has been estimated that $\$ 60$ trillion will be transferred from U.S. estates between 2007 and 2061. ${ }^{77}$ This cohort already frequently participates in philanthropy. For example, David Callahan reports that charitable giving from people making over $\$ 500,000$ annually increased fifty-seven percent from 2003 to 2013; Callahan argues that for the ultra-wealthy with "vast fortunes . . . philanthropy is the only real place the money can go." 78 If the top decile of equity holders contribute half their holdings to the Portfolio, while living or upon death, the Fund would within a few decades come to hold forty percent of all

74. See U.S. Bureau of Econ. Analysis, Corporate Profits After Tax with Inventory Valuation Adjustment (IVA) and Capital Consumption Adjustment (CCAdj), FRED, FED. RES. BANK ST. LouIS (Oct. 27, 2017), https://fred.stlouisfed.org/series/CPATAX [https://perma.cc/6GA6-2MSN].

75. Electorate Profiles: Selected Characteristics of the Citizen, 18 and Older Population, U.S. CENSUS BuREAU (Oct. 28, 2016), https://www.census.gov/data/tables/time-series/demo/voting-andregistration/electorate-profiles-2016.html [https://perma.cc/9QQK-JJKH].

76. William W. Bratton \& Michael L. Wachter, Shareholders and Social Welfare, 36 SeAttle U. L. ReV. 489, 518 (2013) (citing Edward N. Wolff, Recent Trends in Household Wealth in the United States: Rising Debt and the Middle Class Squeeze - An Update to 2007, 58 tbl.15a (Levy Econ. lnst., Working Paper No. 589, 2010), https://papers.ssrn.com/sol3/papers.cfm?abstract_ $\mathrm{id}=1585409$ ).

77. John J. Havens \& Paul G. Schervish, A Golden Age for Philanthropy Still Beckons: National Wealth Transfer and Potential for Philanthropy Technical Report 13 (May 28, 2014) (unpublished manuscript) (on file with Ctr. on Wealth and Philanthropy, Boston Coll.), https://www.bc.edu/content/dam/files/research_sites/cwp/pdf/A\%20Golden\%20Age $\% 20$ of $\% 20 \mathrm{Phila}$ nthropy\%20Still\%20Bekons.pdf [https://perma.cc/UDR7-Q5HU].

78. David Callahan, The Givers: Wealth, Power, and Philanthropy in a New Gilded AGE 18 (2017). 
corporate equities. This proportion would continue to grow as long as the ultra-wealthy choose to contribute.

Second, corporations also have reason to donate their own shares. Contributing to the Fund can appeal to consumers, employees, and investors (consider the success of Google's "Don't Be Evil" strategy during its IPO or current interest in so-called "benefit corporations"). ${ }^{79}$ In addition, because the Fund is a long-term shareholder, donating stock to the Fund will appeal to some public companies as a means of counterbalancing the influence of short-term shareholders, especially activist hedge funds. ${ }^{80}$

Finally, although our proposal assumes the Fund would acquire its Portfolio through donations, the Fund's effectiveness could be accelerated through government support. At a minimum, treating donations to the Fund like other tax-deductible charitable contributions promotes donor interest. More ambitiously, government revenues raised from taxes or other sources could be used to buy shares to place in the Fund. This requires legislative action, but such a policy might enjoy widespread public support given Blueprint's broad benefits.

\section{B. Agency Costs Imposed by Fund Administrators}

Because the value of the Portfolio might measure in the trillions of dollars, it is important to protect against the possibility that Administrators might impose agency costs on Shareholders by shirking or stealing. ${ }^{81}$ Our plan includes several such protective elements.

Perhaps the primary source of Shareholder protection is the very limited discretion granted to Administrators under Blueprint. Unlike managers of a typical mutual fund, Administrators would not be allowed to trade securities or determine how securities in the Portfolio are voted. There is relatively little damage they can do to Shareholders' interests. Their job is indeed purely administrative (maintaining lists of Shareholders and securities in the Portfolio, ensuring dividends are

79. See Kim et al., supra note 14; see also Google Inc., Registration Statement (Form S-1) (Apr. 29, 2004), https://www.sec.gov/Archives/edgar/data/1288776/000119312504073639/ds1.htm\# toc16167_1 [https://perma.cc/C5P6-S4DZ].

80. In effect, donating shares to the Fund becomes a form of anti-takeover protection. See Tamara C. Belinfanti, Shareholder Cultivation and New Governance, 38 DEL. J. CORP. L. 789, 863-64 (2014) (discussing how shareholder cultivation could serve as an anti-takeover defense); Edward B. Rock, Shareholder Eugenics in the Public Corporation, 97 CORNELL L. REV. 849, 865-66 (2012) (discussing how "relational" investors can provide value to the firm or just provide "takeover protection" for managers).

81. See generally Michael C. Jensen \& William H. Meckling, Theory of the Firm: Managerial Behavior, Agency Costs and Ownership Structure, 3 J. FIn. ECON. 305 (1976). 
"passed through" equally to all Shareholders, and ensuring equities in the Portfolio are voted according to Shareholders' directions). Modern information technologies have made these administrative tasks far less costly. ${ }^{82}$

Additional protection against agency costs could be built into the Administrators' compensation. For example, Administrators could be paid a predetermined fee that would not change based on the value or performance of the Portfolio, thus reducing the possibility of perverse incentives.

Finally, various processes could be adopted to maximize the chances that the individuals selected to become Administrators are ethical and representative of Shareholders' interests. For example, Administrators could be periodically elected by Shareholders; drawn at random from the citizenry as jurors are chosen; subject to term limits; selected to represent certain demographics; and so forth.

\section{Reduced Informational Efficiency in Stock Pricing}

Because the Fund would not trade the stocks in its Portfolio, the larger the percentage of a company's shares held by the Fund, the less trading there is likely to be in that company's shares. This may reduce the "informational efficiency" of the market price of the company's shares. ${ }^{83}$ A similar concern has been raised with regard to index funds, which also trade rarely. ${ }^{84}$

However, so long as any significant portion of a company's shares are owned and traded by individual or institutional shareholders outside the Fund, market prices are likely to remain at least somewhat informationally efficient. Moreover, it can be argued that the benefits associated with marginal increases in informational efficiency are small. ${ }^{85}$ Finally, it is not clear that companies need publicly-reported stock prices

82. See supra text accompanying note 18 (discussing mutual fund administrative costs).

83. See generally Ronald J. Gilson \& Reinier H. Kraakman, The Mechanisms of Market Efficiency, 70 VA. L. REV. 549 (1984).

84. See Eric Belasco, Michael Finke \& David Nanigian, The Impact of Passive Investing on Corporate Valuations, 38 MANAGERIAL FIN. 1067, 1082 (2012); James Ledbetter, Is Passive Investment Actively Hurting the Economy?, NEW YORKER (Mar. 9, 2016), https:/www.newyorker.com/business/currency/is-passive-investment-actively-hurting-the-economy.

85. See generally Lynn A. Stout, The Unimportance of Being Efficient: An Economic Analysis of Stock Market Pricing and Securities Regulation, 87 MiCH. L. REV. 613 (1988). Market efficiency is most important when companies are issuing equity to raise capital (which happens rarely, see $i d$. at 645-47); when executive pay is tied to share price (which Shareholders could change, see supra notes 6,56 (discussing Shareholder reform of executive compensation)); and when control of a company is purchased by acquiring its stock (which happens rarely and generally only in response to dramatic share price declines, see Stout, supra note 85, at 685-92 (discussing stock price in takeovers)). 
at all to function effectively, as demonstrated by the long-term success of many private companies.

\section{Logistics of Shareholder Voting}

Voting the shares of companies to improve corporate performance is a classic common good; one shareholder incurs all the costs of becoming informed and casting their votes, and all shareholders enjoy the resulting benefits. Thus, it can be expected that many shareholders will be disinclined to become informed and vote. Like most present-day individual shareholders, Shareholders will be "rationally apathetic." 86

This can be ameliorated by requiring the Administrators to dedicate some percentage of the income received by the Fund to pay proxy advisory firms selected by the Shareholders. Like today's proxy advisory services, these services would develop voting guidelines that direct the Administrators on how to vote the portion of the shares in the portfolio attributable to the Shareholders who selected that service. Because the Fund will pay fees in proportion to the number of Shareholders who select a particular proxy service, incentives are created to develop new services that cater to Shareholders on the basis of the quality of their voting guidelines, rather than low cost. Such new proxy advisory services would take better account of Shareholders' stronger preferences for long-term financial performance and for better corporate social, environmental, and ethical performance.

Using new information technologies, individual Shareholders could also be given the option to directly inform Administrators how to vote their portion of the shares held in the Portfolio. But, unless Shareholders are compensated for doing so, rational apathy is likely to deter them. This may be desirable; share voting guidelines developed by competing proxy services would likely be more informed and efficient than voting decisions made by relatively uninformed individual Shareholders. Although Shareholders would still need to inform themselves about the quality and nature of competing proxy services, this is a much less burdensome task than becoming informed about the performance of all the companies whose shares are held in the Portfolio. Shareholders could further be encouraged to select a proxy service by making a Shareholder's receipt of payments from the Fund contingent on doing so.

86. Lisa M. Fairfax, The Future of Shareholder Democracy, 84 IND. L.J. 1260, 1268-69 (2009) (discussing rational shareholder apathy). 


\section{E. The Risk of Irrational or Antisocial Shareholder Preferences}

Some readers might fear that Shareholders, if given a greater role in corporate governance, might make even worse decisions than today's institutional shareholders and proxy advisory services. In particular, Shareholders might prove even more short-sighted, or even more willing to impose external costs and withhold external benefits in the pursuit of personal financial gain.

This paternalistic critique implicitly assumes significantly superior foresight on the part of institutional investors who are presumed to participate in corporate governance in a fashion that serves their beneficiaries' best interests. This outcome is highly unlikely given the perverse incentives institutional investors face. ${ }^{87}$ Given the very short stock holding periods typical of today's institutional investors, and the much longer time frame of Shareholders, it is extremely unlikely that empowering Shareholders could make the problem of short-termism worse.

There is also reason to believe that Shareholders would be much more interested in the problems of constraining corporate external costs and maximizing corporate social benefits than the institutional fund managers that dominate corporate governance today are. This is because, compared to fund managers, Shareholders are more vulnerable to corporate external costs like job losses or environmental pollution, and are more dependent on corporate external benefits like skills training or quality products. Similarly, they may be more interested in promoting corporate political transparency than the ultra-wealthy, who are more likely to benefit from corporate rent-seeking.

\section{CONCLUSION}

In this Article, we have provided a thumbnail sketch of a proposal to address many currently pressing social and economic problems and, in the process, restore public faith in the idea of a democratic capitalism that serves the vast majority of people. We have shown how implementing Blueprint would provide a number of significant benefits and is unlikely to present any dangers. Practical challenges exist, but they can be overcome. The only real question is the degree to which Blueprint is implemented and its potential benefits become a reality.

Our proposal, however, faces another obstacle: certain widely held, often unconscious, and fundamentally erroneous beliefs about how the world works. We mention some of these psychological hurdles below in 
the hope that drawing attention to them and to their inaccuracy can temper their effect.

The first erroneous belief is the often-automatic assumption that all policy problems must be solved either through market forces or by government intervention. This assumption overlooks the demonstrated reality that private ordering often provides a third way, superior to either free markets or regulation, for addressing certain economic and social problems. History has shown that private organizations are capable of amassing enormous assets and exercising great influence. ${ }^{88}$ Consider, for example, the Red Cross, the Sierra Club, private universities, and the Catholic Church. Modern business corporations - some of which rival nation-states in their power and influence - are yet another example of the power of private ordering. Corporations emerged as private ordering solutions to the problem of aggregating resources to pursue long-term, large-scale, and uncertain projects requiring specific investments. ${ }^{89}$ By proposing Blueprint, we simply take the concept of private ordering as a policy solution to the next level.

A second psychological hurdle to implementing Blueprint is the common, but empirically incorrect, assumption that human beings are purely selfish actors concerned only with amassing financial wealth. This often-unconscious assumption, which is a staple of more-superficial economic analysis, has been definitively proven false by innumerable research studies in cognitive psychology, behavioral economics, developmental psychology, anthropology, neuroscience, evolutionary science, social psychology, and biology. ${ }^{90}$ It also flies in the face of centuries of human altruism and devotion to nonprofit endeavors, not to mention present-day individual and corporate philanthropy. Given this reality, it is not implausible that Blueprint could be organized and funded in reliance upon some degree of human altruism.

Finally, there is a natural human tendency to assume that any policy solution or arrangement we have not seen at work before must suffer from some fundamental flaw and cannot work in the future. In the past, this tendency has motivated resistance to many important social changes we now recognize to be beneficial. Examples include the adoption of representative democracy, the abolition of human slavery, free public

88. See generally Avery Katz, Taking Private Ordering Seriously, 144 U. PA. L. ReV. 1745 (1996); Steven L. Schwarz, Private Ordering, 97 Nw. U. L. REV. 319 (2002).

89. See generally Margaret M. Blair, Locking in Capital: What Corporate Law Achieved for Business Organizers in the Nineteenth Century, 51 UCLA L. REV. 387 (2004); Schwartz, supra note 46; Stout, supra note 46.

90. See generally Robert M. SAPOlsky, Behave: The Biology of Humans at Our Best AND WORST (2017); ELLIOTT SOBER \& DAVID SLOAN-WILSON, UNTO OTHERS: THE EVOLUTION AND PSYCHOLOGY OF UNSELFISH BEHAVIOR (1998); STOUT, supra note 71. 
education, and the granting of full legal rights to women. As these examples illustrate, we would do well to believe we can do better in the future than we have done in the past. This Blueprint for Citizen Capitalism provides a hopeful path to such a better future. 